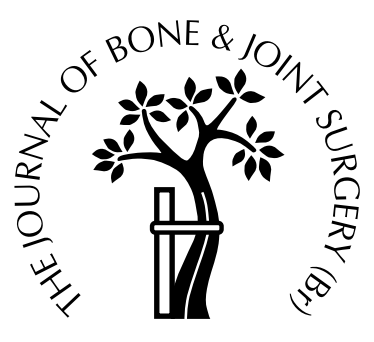

\title{
Effect of displacement of fractures of the greater tuberosity on the mechanics of the shoulder
}

\author{
C. M. Bono, R. Renard, R. G. Levine, A. S. Levy \\ From New Jersey Medical School, Newark, USA
}

$\mathbf{U}$

sing a dynamic biomechanical model of malunion of the shoulder, we have determined the change in deltoid force required for abduction with various combinations of superior and posterior displacement of fractures of the greater tuberosity of the humerus. We tested eight fresh human cadaver shoulders in a dynamic shoulder-testing apparatus during cycles of glenohumeral abduction from $0^{\circ}$ to $90^{\circ}$. The greater tuberosities were osteotomised and stabilised to represent malunion with combinations of superior and posterior displacements of $1 \mathrm{~cm}$ and less. The peak force was measured for each displacement in each specimen and statistically compared with values of no displacement using a repeated-measures analysis of variance.

The abduction force was significantly increased by $16 \%(p=0.006)$ and $27 \%(p=0.0001)$ by superior displacements of $0.5 \mathrm{~cm}$ and $1 \mathrm{~cm}$, respectively, while combined superior and posterior displacement of $1 \mathrm{~cm}$ gave an increase in force of $29 \%(p=0.001)$. While treatment criteria for acceptable residual displacement of the greater tuberosity are widely used, there is little information on the direct biomechanical effects of displacement on shoulder mechanics. Although the results of conservative treatment are influenced by a number of factors, including associated injuries, rehabilitation and the pre-existing function of the shoulder, our data suggest that small amounts of

C. M. Bono, MD, Clinical Instructor

Department of Orthopaedics, University of California, San Diego, School of Medicine, 200 West Arbor Drive, 8894, San Diego, California 92103, USA.

R. Renard, MS, Biomechanical Engineer

Department of Orthopaedic Surgery, Orthopaedic Research Laboratory, New Jersey Medical School, University of Medicine and Dentistry of New Jersey, Medical Science Building, G-574, 185 South Orange Avenue, Newark, New Jersey 07103, USA

R. G. Levine, MD, Attending Surgeon

Union Memorial Hospital, Baltimore, Maryland, USA

A. S. Levy, MD, Attending Surgeon

Centre for Orthopaedic Sports Medicine, Knee and Shoulder, Newark, New Jersey 07107, USA.

Correspondence should be sent to Dr C. M. Bono.

(C)2001 British Editorial Society of Bone and Joint Surgery 0301-620X/01/710516\$2.00 residual displacement may alter the balance of forces required to elevate the arm at the glenohumeral joint.

J Bone Joint Surg [Br] 2001;83-B:1056-62.

Received 2 September 1999; Accepted after revision 17 August 2000

The most widely used objective criterion for the treatment of fractures of the greater tuberosity is the amount of initial displacement. ${ }^{1-6}$ Most authors advocate conservative treatment of fractures with less than $0.5 \mathrm{~cm}$ of displacement and surgery for injuries in which it is more than $1.0 \mathrm{~cm},{ }^{1,2,4,6}$ but the optimal management of fragments with distraction of between 0.5 and $1.0 \mathrm{~cm}$ is unclear. With displacement there is often loss of shoulder abduction ${ }^{2,4,7}$ which has been attributed to an alteration of the function of the rotator cuff ${ }^{8}$ and a direct mechanical block. ${ }^{3,7}$ In addition, superior or posterior malalignment of the greater tuberosity can lead to its prominence causing painful impingement. ${ }^{5}$

In order to understand better the relationship between displacement and the mechanics of abduction of the shoulder, we have attempted to ascertain the effects in vitro of malunion of the greater tuberosity. Specifically, we have investigated the influence of displacement of superior and posterior fractures on abduction forces in a dynamic shoulder model.

\section{Materials and Methods}

Preparation of specimens. We obtained eight freshly frozen human cadaver shoulders from individuals ranging in age from 43 to 81 years which were stored at a constant $20^{\circ} \mathrm{C}$ below zero in a commercial-grade freezer. The specimens were thawed at room temperature for immediate dissection and testing. Skin and subcutaneous tissue were carefully stripped and deep dissection around the scapula included meticulous delineation of all the musculotendinous borders of the rotator cuff. The borders of the deltoid muscle were outlined in their entirety and the distal insertion into the deltoid groove of the humerus and the proximal attachments on to the acromion and clavicle were noted. The trapezius muscles were reflected and resected from their scapular and clavicular origins giving full exposure of the supraspinatus muscle and tendon. The insertions of the tendon of the rotator cuff were traced laterally to 


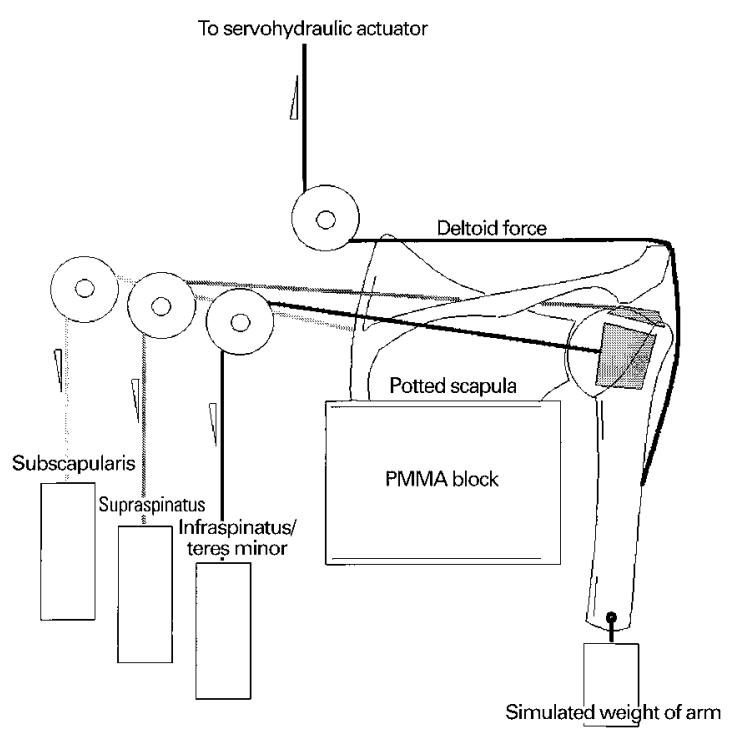

Fig. 1a

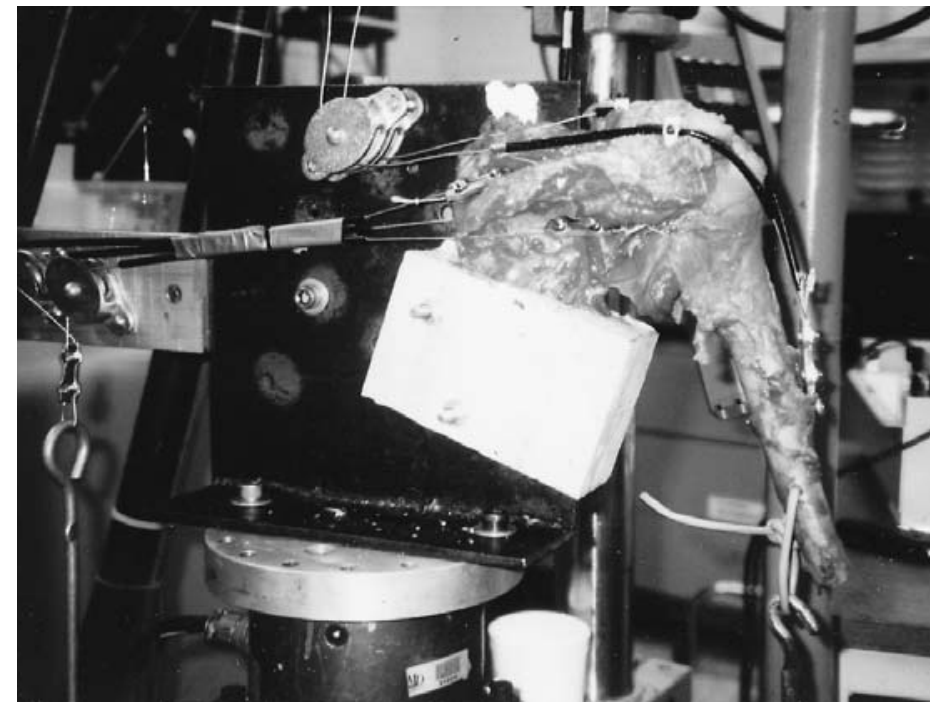

Fig. 1b

Diagram (a) and photograph (b) of the shoulder testing apparatus.

their attachments on the greater tuberosity. All the specimens were inspected to check the integrity of the bone, rotator cuff, and joint capsule integrity and those with evidence of acute or chronic tears of the cuff, previous fractures or malunion of the proximal humerus, or previous acromioplasty or resection of the acromion were excluded. Tissue hydration was maintained throughout the experiment by intermittent irrigation with a saline spray warmed to $98.6^{\circ} \mathrm{F}$.

After meticulous dissection, the tendons of the rotator cuff (supraspinatus, infraspinatus, teres minor and subscapularis) were transected approximately at the level of the musculotendinous junction, leaving a cuff of $0.5 \mathrm{~cm}$ for subsequent fixation to the testing apparatus. The muscle bellies were carefully elevated from their respective fossae on the scapula. S-shaped hooks $(2.54 \mathrm{~cm}, 18 \mathrm{~kg})$ were sutured into the tendon at their medial borders with a No. 5 braided non-absorbable suture in a modified Bunnell stitch and reinforced with one loop of 12-gauge surgical steel wire. The lower halves of the scapulae were stripped of soft tissues and placed in a block of polymethylmethacrylate bone cement, $9 \times 15 \mathrm{~cm}$ in size.

Shoulder testing apparatus. The dynamic-active testing apparatus is a novel design adapted from previously validated systems. ${ }^{9-11}$ Two steel plates welded at a right angle served as the fixation pedestal to the base of the servohydraulic machine. Two parallel open-ended pulleys at the superior midpoint of the backplate, directed anteriorly, carried middle deltoid cables, fixed at the insertion of the deltoid tendon, to the servohydraulic actuator. A medial side arm supported three pulleys in series serving to transfer downward forces of hanging weights to the infraspinatus/teres minor, supraspinatus, and subscapularis tendon cables along their physiological centroids.
The specimens were then bolted to the upright plate of the apparatus with the medial scapular border orientated vertically (Fig. 1). The clavicles were fixed in the anatomical position by a cortical screw cemented to the upright plate in right-sided specimens or to the medial scapular spine in left-sided specimens. Low-friction sheathed bicycle brake cables were used to transmit deltoid and cuff forces. The anterior and middle deltoid cables passed through two small plastic arches on the lateral acromion and clavicle to localise transmission of force across the approximated muscle centroids and to limit excursion. The ends of the cables converged on a bicortical screw at the deltoid tuberosity. Proximally, the deltoid cables were fixed to the servohydraulic actuator via a 1000 Newton load cell. The same $22 \mathrm{~N}$ weight was attached $4 \mathrm{~cm}$ distal to the insertion of the deltoid of each specimen simulating a standardised weight of the distal extremity. Three rotatorcuff cables passing medially along the muscle centroids linked tendons of the cuff to free-hanging weights which provided constant forces, eliminating the effects of creep and stretch of the tendon fibres and suture-cable complex. After an initial trial of abduction to $90^{\circ}$ the cuff weights were serially adjusted to reflect $16 \%, 28 \%$ and $38 \%$ of the measured deltoid force for the supraspinatus, infraspinatus/ teres minor, and subscapularis, respectively. This approximated to the proportional muscular forces observed in previous published investigations in vivo. ${ }^{12}$

Fracture simulation. An osteotomy of the greater tuberosity was meticulously created from anterior to posterior with a $0.64 \mathrm{~cm}$ oscillating saw along the lateral border of the intertubercular groove, without violation of the humeral insertions of the tendons of the rotator cuff. The fragmenttendon complex, containing the insertions of the supraspinatus and infraspinatus/teres minor muscles, was then 


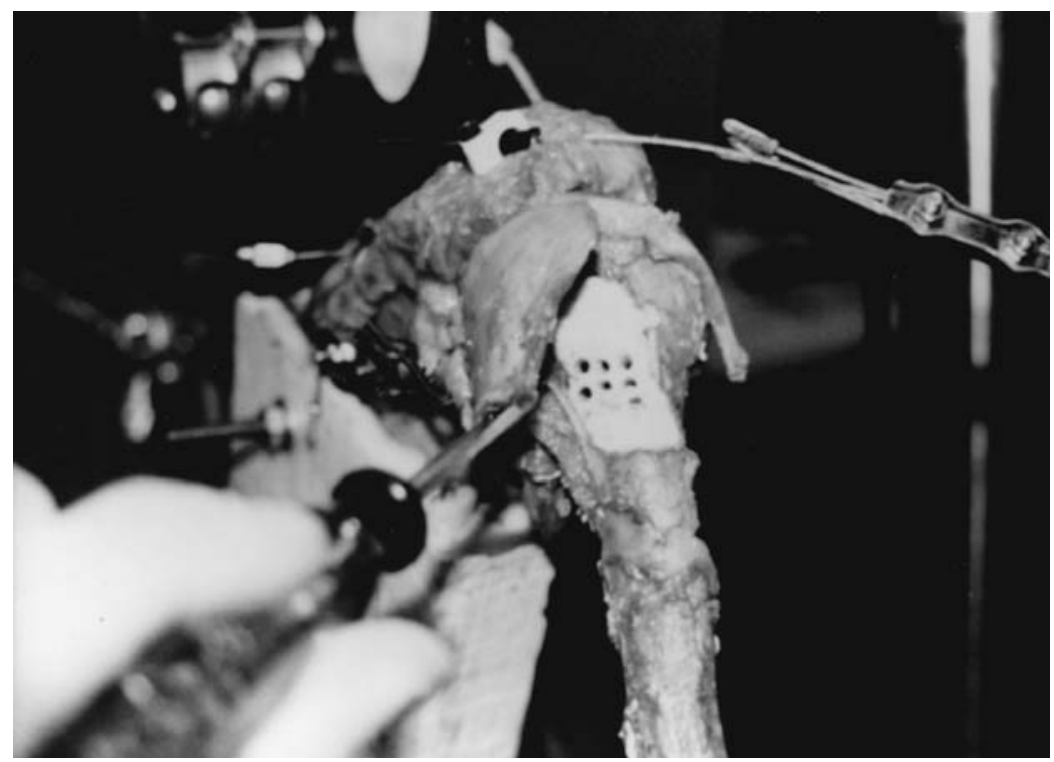

Fig. 2

With the fragment held reflected, $2.5 \mathrm{~mm}$ holes were drilled and tapped at measured displacements with respect to the orientation hole within the cement: superior $1.0 \mathrm{~cm}$, superior $0.5 \mathrm{~cm} /$ posterior $0.5 \mathrm{~cm}$, superior $0.5 \mathrm{~cm} /$ posterior $1.0 \mathrm{~cm}$, superior $1.0 \mathrm{~cm} /$ posterior $0.5 \mathrm{~cm}$ and superior $1.0 \mathrm{~cm} /$ posterior $1.0 \mathrm{~cm}$.

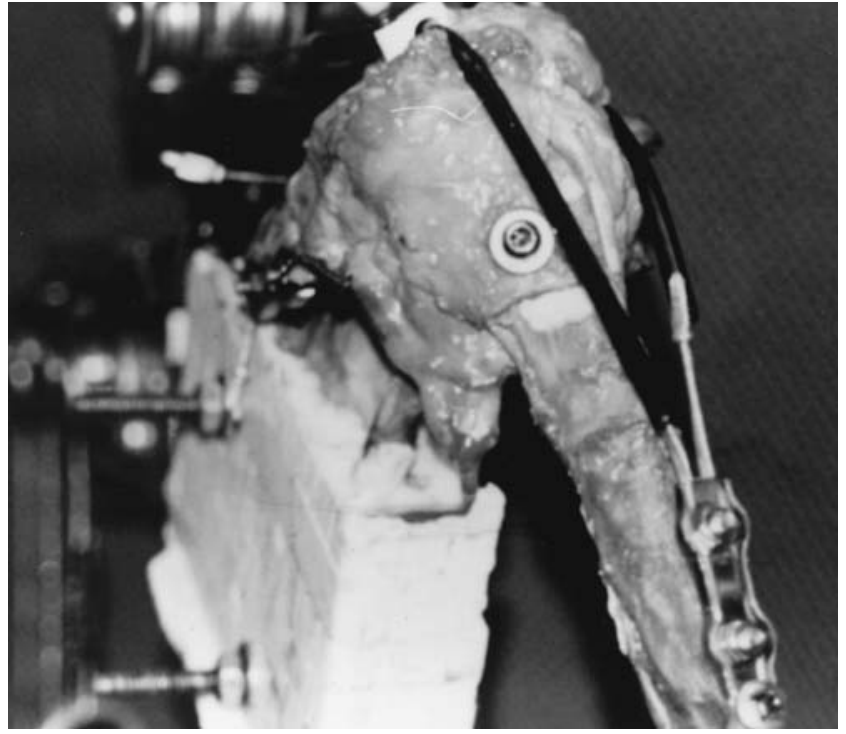

Fig. 3

One $3.2 \mathrm{~mm}$ fully threaded cortical bone screw was used to attach the greater tuberosity securely at each displacement, simulating a healed malunion.

reflected posteriorly and superiorly to allow access to the underlying cancellous bone. The exposed cancellous bone was atraumatically excavated using a sharp curette to a depth of $2 \mathrm{~cm}$ and filled with polymethylmethacrylate flush to the cortical borders of the osteotomy. Bone cement was used since it is a strong and durable medium to which the fragment of the tuberosity could be fixed in increments of measured displacement. At the hard-doughy state of the cement, trial reduction of the fragment was carried out to confirm anatomical fit. With the fragment held reduced after hardening of the cement, an orientation hole was drilled with a $2.5 \mathrm{~mm}$ bit through the hard cortical bone of the distal aspect of the fragment into the cement. With the fragment held reflected, $2.5 \mathrm{~mm}$ holes were drilled and tapped at measured displacements with respect to the orientation hole within the cement: superior $1.0 \mathrm{~cm}$, superior $0.5 \mathrm{~cm} /$ posterior $0.5 \mathrm{~cm}$, superior $0.5 \mathrm{~cm} /$ posterior $1.0 \mathrm{~cm}$, superior $1.0 \mathrm{~cm} /$ posterior $0.5 \mathrm{~cm}$ and superior $1.0 \mathrm{~cm} /$ posterior $1.0 \mathrm{~cm}$ (Fig. 2). A $3.2 \mathrm{~mm}$ drill bit was used to overdrill the hole in the fragment of the tuberosity to allow compression. One $3.2 \mathrm{~mm}$ fully-threaded cortical bone screw was used to attach the greater tuberosity securely at each displacement, simulating a healed malunion (Fig. 3), Testing of specimens. The deltoid cable force was continuously measured during three uniform cycles of movement from $0^{\circ}$ to $90^{\circ}$ of elevation in the scapular plane for each specimen at each displacement. With forces being independent of rate, a sufficiently slow loading rate of $0.3 \%$ was used to eliminate the confounding effects of acceleration/deceleration of the cable-operated system since the model uses unopposed abduction agonists. Intact shoulder specimens were tested before osteotomy. Each osteotomised specimen was first tested at zero displacement to determine the effects of the osteotomy on observed forces. Subsequently, each was tested at each displacement combination in varying orders. During each testing cycle, the presence or absence of direct contact of the greater tuberosity on the lateral or undersurface of the acromion was noted and recorded.

Analysis of data. Displacements and forces were recorded using MTS Teststar II software (Minneapolis, Minnesota) and transferred to Microsoft Excel for analysis of data, which were graphically displayed and the peak abduction force recorded. Peak forces were statistically analysed using a repeated-measures analysis-of-variance software program (SuperANOVA) for significance between and within specimens and confidence intervals were determined (Fig. 4). 


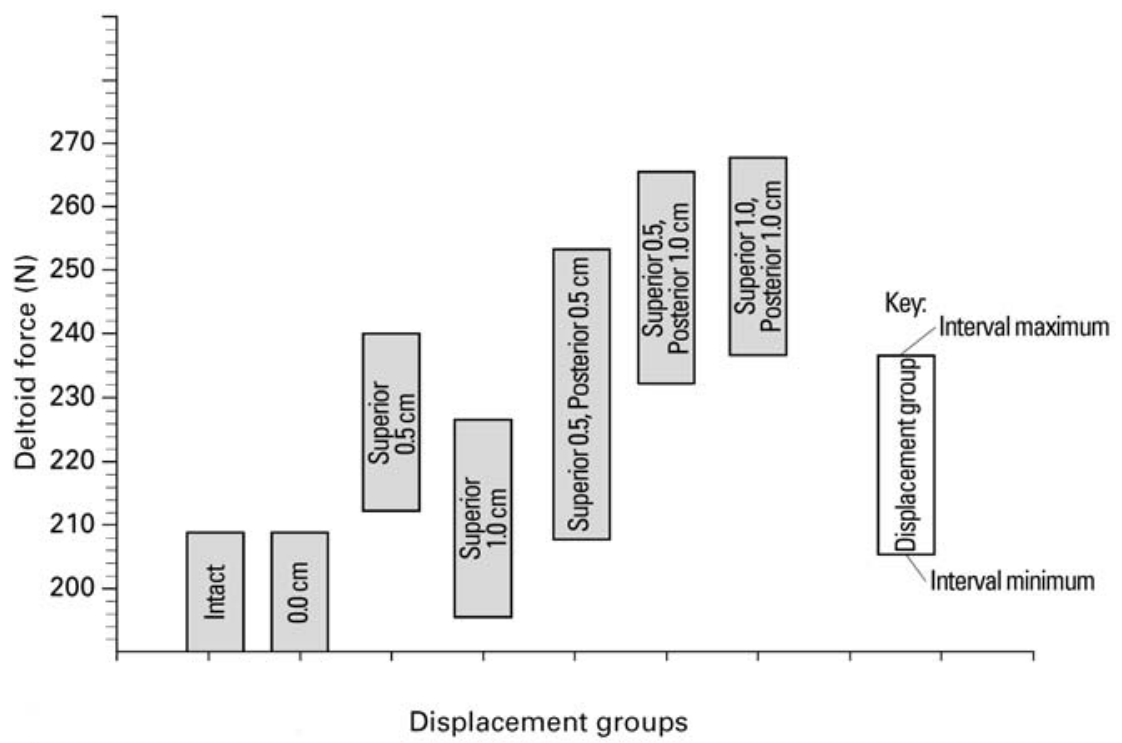

Fig. 4

Graphical representation of $95 \%$ confidence intervals for each displacement group.

\section{Results}

Displacement of all combinations (Tables I and II) except one caused a significant increase in the abduction force of the deltoid when compared with no displacement $(p<0.01)$. Forces with superior displacement of $0.5 \mathrm{~cm}$ were significantly increased $(\mathrm{p}<0.01)$ representing an increase of force requirement of $16 \%$. Superior $0.5 \mathrm{~cm} /$ posterior $0.5 \mathrm{~cm}$ displacement did not cause a detectable increase in abduction force $(\mathrm{p}>0.01)$. There was no significant difference between intact and post-osteotomised non-displaced specimens $(\mathrm{p}=0.99)$. Abduction forces with $1.0 \mathrm{~cm}$ superior and superior $1.0 \mathrm{~cm} /$ posterior $1.0 \mathrm{~cm}$ were significantly greater than forces with $0.5 \mathrm{~cm}$ superior displacement $(\mathrm{p}<0.005)$. The significant increase with $0.5 \mathrm{~cm}$ superior displacement became insignificant with additional posterior displacement of $0.5 \mathrm{~cm}$. Subacromial contact was observed with superior $1.0 \mathrm{~cm} /$ posterior $1.0 \mathrm{~cm}$ and superior $0.5 \mathrm{~cm} /$ posterior $1.0 \mathrm{~cm}$ displacements in eight and seven specimens, respectively. Superior displacement of $1.0 \mathrm{~cm}$ also caused anatomical impingement in seven specimens, while superior displacement of $0.5 \mathrm{~cm}$ impinged in only one case.

\section{Discussion}

The conservative treatment of fractures of the greater tuberosity has led to variable outcomes. Neer ${ }^{1}$ endorsed conservative treatment of fractures which were displaced less than $1.0 \mathrm{~cm}$, stating that early functional rehabilitation and range of movement resulted in a satisfactory outcome. In a series of 79 fractures of the greater tuberosity including displaced and non-displaced injuries, Olivier, Duparc and Romain $^{13}$ documented unsatisfactory results in $31 \%$, while Rasmussen et al $^{6}$ found excellent or satisfactory outcomes with conservative treatment. Young and Wallace ${ }^{14}$ reported good or acceptable results in $97 \%$ of cases with con- servative treatment of minimally displaced injuries of the greater tuberosity, qualifying abduction greater than $60^{\circ}$ as acceptable.

Recently, many surgeons have expanded their surgical indications. Craig ${ }^{4}$ endorses surgical fixation of fractures which are displaced by $0.5 \mathrm{~cm}$ to $1.0 \mathrm{~cm}$ to minimise dysfunction. Similarly, Iannotti and Sidor ${ }^{2}$ recommend operative fixation of fractures which are displaced by $0.5 \mathrm{~cm}$ or more to decrease the incidence of impingement and loss of forward elevation. Supportingly, Flatow et al ${ }^{15}$ reported an average abduction of $170^{\circ}$ with mild or no pain in 12 patients treated surgically for displaced fractures, while Park et al ${ }^{16}$ reported good to excellent results in 14 patients treated operatively. ${ }^{16}$ Although these data are limited, they indicate excellent movement and functional results after surgical fixation of these injuries.

Explanations for poor results after conservative treatment of fractures of the greater tuberosity have included loss of shoulder elevation and painful movement. ${ }^{2,3,5,7}$ An alteration of the function of the rotator cuff $^{8}$ and a direct mechanical block ${ }^{3,7}$ may compromise abduction. Prominence of the greater tuberosity with superior or posterior displacement may contribute to symptomatic subacromial impingement. ${ }^{5}$

Clinically, loss of shoulder abduction can be influenced by a number of factors, including a tear of the rotator cuff, painful movement, rehabilitation and concomitant nerve palsy. The biomechanical effects of greater displacement of a fracture of the tuberosity must also be considered. With the supraspinatus tendon inserting on the fragment, we postulate that displacement effectively changes the force vectors of this muscle. This seems likely since previous studies ${ }^{12,17-19}$ have highlighted the importance of the supraspinatus in aiding shoulder abduction. In a mechanical study, Thompson et $\mathrm{al}^{20}$ showed an increase of $101 \%$ in deltoid force required with a simulated paralysis of the supraspinatus, and an inability to abduct the shoulder great- 
Table I. Observed data of the effect of combinations of displacement on mean (SD) peak force for the eight specimens

\begin{tabular}{|c|c|c|c|c|c|}
\hline Specimen & $\begin{array}{l}\text { Age } \\
(\mathbf{y r})\end{array}$ & Side & $\begin{array}{l}\text { Displacement } \\
\text { (cm) }\end{array}$ & $\begin{array}{l}\text { Peak force } \\
\text { (three cycle mean } \\
\text { in Newtons) }\end{array}$ & $\begin{array}{l}\text { Observed } \\
\text { anatomical } \\
\text { impingement }\end{array}$ \\
\hline 1 & 75 & Left & $\begin{array}{l}\text { Intact } \\
0.0 \\
\text { Superior } 0.5 \\
\text { Superior } 1.0 \\
\text { Superior } 0.5 \text {, posterior } 0.5 \\
\text { Superior } 0.5 \text {, posterior } 1.0 \\
\text { Superior } 1.0 \text {, posterior } 1.0\end{array}$ & $\begin{array}{l}177 \pm 2 \\
178 \pm 2 \\
216 \pm 5 \\
220 \pm 15 \\
192 \pm 4 \\
175 \pm 1 \\
223 \pm 5\end{array}$ & $\begin{array}{l}\text { None } \\
\text { None } \\
\text { None } \\
\text { Yes } \\
\text { None } \\
\text { Yes } \\
\text { Yes }\end{array}$ \\
\hline 2 & 62 & Left & $\begin{array}{l}\text { Intact } \\
0.0 \\
\text { Superior } 0.5 \\
\text { Superior } 1.0 \\
\text { Superior } 0.5 \text {, posterior } 0.5 \\
\text { Superior } 0.5 \text {, posterior } 1.0 \\
\text { Superior } 1.0 \text {, posterior } 1.0\end{array}$ & $\begin{array}{l}167 \pm 0 \\
169 \pm 1 \\
250 \pm 10 \\
242 \pm 7 \\
180 \pm 18 \\
253 \pm 13 \\
225 \pm 0\end{array}$ & $\begin{array}{l}\text { None } \\
\text { None } \\
\text { None } \\
\text { Yes } \\
\text { None } \\
\text { None } \\
\text { Yes }\end{array}$ \\
\hline 3 & 43 & Right & $\begin{array}{l}\text { Intact } \\
0.0 \\
\text { Superior } 0.5 \\
\text { Superior } 1.0 \\
\text { Superior } 0.5 \text {, posterior } 0.5 \\
\text { Superior } 0.5 \text {, posterior } 1.0 \\
\text { Superior } 1.0 \text {, posterior } 1.0\end{array}$ & $\begin{array}{l}181 \pm 0 \\
180 \pm 1 \\
220 \pm 2 \\
269 \pm 1 \\
192 \pm 2 \\
195 \pm 6 \\
253 \pm 3\end{array}$ & $\begin{array}{l}\text { None } \\
\text { None } \\
\text { None } \\
\text { Yes } \\
\text { None } \\
\text { Yes } \\
\text { Yes }\end{array}$ \\
\hline 4 & 81 & Left & $\begin{array}{l}\text { Intact } \\
0.0 \\
\text { Superior } 0.5 \\
\text { Superior } 1.0 \\
\text { Superior } 0.5 \text {, posterior } 0.5 \\
\text { Superior } 0.5 \text {, posterior } 1.0 \\
\text { Superior } 1.0 \text {, posterior } 1.0\end{array}$ & $\begin{array}{l}243 \pm 1 \\
242 \pm 2 \\
277 \pm 4 \\
279 \pm 3 \\
238 \pm 0 \\
244 \pm 1 \\
268 \pm 3\end{array}$ & $\begin{array}{l}\text { None } \\
\text { None } \\
\text { Yes } \\
\text { Yes } \\
\text { None } \\
\text { Yes } \\
\text { Yes }\end{array}$ \\
\hline 5 & 77 & Left & $\begin{array}{l}\text { Intact } \\
0.0 \\
\text { Superior } 0.5 \\
\text { Superior } 1.0 \\
\text { Superior } 0.5 \text {, posterior } 0.5 \\
\text { Superior } 0.5 \text {, posterior } 1.0 \\
\text { Superior } 1.0 \text {, posterior } 1.0\end{array}$ & $\begin{array}{l}159 \pm 1 \\
162 \pm 1 \\
173 \pm 2 \\
180 \pm 1 \\
208 \pm 14 \\
185 \pm 0 \\
219 \pm 5\end{array}$ & $\begin{array}{l}\text { None } \\
\text { None } \\
\text { None } \\
\text { None } \\
\text { None } \\
\text { Yes } \\
\text { Yes }\end{array}$ \\
\hline 6 & 59 & Right & $\begin{array}{l}\text { Intact } \\
0.0 \\
\text { Superior } 0.5 \\
\text { Superior } 1.0 \\
\text { Superior } 0.5 \text {, posterior } 0.5 \\
\text { Superior } 0.5 \text {, posterior } 1.0 \\
\text { Superior } 1.0 \text {, posterior } 1.0\end{array}$ & $\begin{array}{l}170 \pm 2 \\
169 \pm 1 \\
193 \pm 1 \\
223 \pm 3 \\
169 \pm 2 \\
203 \pm 0 \\
239 \pm 2\end{array}$ & $\begin{array}{l}\text { None } \\
\text { None } \\
\text { None } \\
\text { Yes } \\
\text { None } \\
\text { Yes } \\
\text { Yes }\end{array}$ \\
\hline 7 & 68 & Right & $\begin{array}{l}\text { Intact } \\
0.0 \\
\text { Superior } 0.5 \\
\text { Superior } 1.0 \\
\text { Superior } 0.5 \text {, posterior } 0.5 \\
\text { Superior } 0.5 \text {, posterior } 1.0 \\
\text { Superior } 1.0 \text {, posterior } 1.0\end{array}$ & $\begin{array}{l}222 \pm 2 \\
221 \pm 1 \\
228 \pm 5 \\
271 \pm 6 \\
226 \pm 2 \\
240 \pm 3 \\
258 \pm 2\end{array}$ & $\begin{array}{l}\text { None } \\
\text { None } \\
\text { None } \\
\text { Yes } \\
\text { None } \\
\text { None } \\
\text { Yes }\end{array}$ \\
\hline 8 & 71 & Left & $\begin{array}{l}\text { Intact } \\
0.0 \\
\text { Superior } 0.5 \\
\text { Superior } 1.0 \\
\text { Superior } 0.5 \text {, posterior } 0.5 \\
\text { Superior } 0.5 \text {, posterior } 1.0 \\
\text { Superior } 1.0 \text {, posterior } 1.0\end{array}$ & $\begin{array}{l}241 \pm 2 \\
239 \pm 1 \\
252 \pm 3 \\
308 \pm 1 \\
284 \pm 0 \\
345 \pm 6 \\
333 \pm 2\end{array}$ & $\begin{array}{l}\text { None } \\
\text { None } \\
\text { Yes } \\
\text { Yes } \\
\text { None } \\
\text { Yes } \\
\text { Yes }\end{array}$ \\
\hline
\end{tabular}

Table II. Calculated data for the effect of displacement on the mean ( \pm SD) peak force

\begin{tabular}{lllllll}
\hline $\begin{array}{l}\text { Displacement } \\
(\mathbf{c m})\end{array}$ & $\begin{array}{l}\text { Average force } \\
\text { (all specimens) }\end{array}$ & $\begin{array}{l}\text { Difference } \\
(\mathbf{N})\end{array}$ & $\begin{array}{l}\text { Percentage } \\
\text { increase }\end{array}$ & $\begin{array}{l}\text { 95\% confidence } \\
\text { interval }\end{array}$ & $\begin{array}{l}\text { p value } \\
(\boldsymbol{v} \text { intact })\end{array}$ & $\begin{array}{l}\mathbf{p} \text { value } \\
(\boldsymbol{v} \mathbf{0 . 5} \mathbf{~ c m})\end{array}$ \\
\hline Intact & $195 \pm 33$ & & & 181 to 209 & & \\
0.0 & $195 \pm 32$ & 0.0 & 0.0 & 181 to 210 & 0.999 & \\
Superior 0.5 & $226 \pm 32$ & 31.3 & 15.8 & 213 to 240 & 0.0062 & \\
Superior 1.0 & $211 \pm 39$ & 16.2 & 27.2 & 232 to 266 & 0.0001 & 0.0472 \\
Superior 0.5, posterior 0.5 & $231 \pm 36$ & 35.7 & 18.4 & 196 to 227 & 0.153 & - \\
Superior 0.5, posterior 1.0 & $248 \pm 53$ & 53.8 & 27.6 & 207 to 253 & 0.0019 & 0.700 \\
Superior 1.0, posterior 1.0 & $252 \pm 35$ & 57.2 & 29.2 & 237 to 267 & 0.0001 & 0.0228 \\
\hline
\end{tabular}


er than $25^{\circ}$ with a global tear of the supraspinatus. Similarly, Wuelker et $\mathrm{al}^{19}$ observed a decrease of $6 \%$ in abduction with a simulated paralysis of the supraspinatus in a similar testing model in vitro.

Our study shows statistically significant increases in force necessary to abduct the arm to $90^{\circ}$ with displacement of the fracture by as little as $0.5 \mathrm{~cm}$ in vitro. We believe that superior displacement of the tuberosity divides the normally primarily medial component of the supraspinatus force into a medial and inferior component. In effect, a portion of the muscle's pull is directed downwards and can no longer contribute to abduction of the shoulder. It may be inferred from the data that a critical change occurs between zero displacement and $0.5 \mathrm{~cm}$ superior displacement.

A small amount of posterior displacement appeared effectively to reverse the increased deltoid forces observed with displacement of $0.5 \mathrm{~cm}$. In an anatomical study, Minagawa et $\mathrm{al}^{21}$ demonstrated that the supraspinatus inserts primarily $(75 \%)$ on to the anterior half of the greater tuberosity. Assuming that the centroid force of a tendon lies at its mid-point, the pull of supraspinatus may be located anatomically anterior to the central axis of the humerus. With initial posterior translation of $0.5 \mathrm{~cm}$ of a fracture of the greater tuberosity the pull of supraspinatus may be moved in line with the central axis, effectively contributing more to elevation of the arm.

With further posterior displacement $(1.0 \mathrm{~cm})$, the centroid of the muscle may be translated posterior to the central axis of the humeral head. This may account for the significant increase in abduction forces $(p<0.05)$ observed in the experimental model with posterior translations of $1.0 \mathrm{~cm}$. With further posterior displacement, a portion of the muscle's medial force is lost to serve as an external rotator of the humerus.

A direct mechanical block may contribute resistance to elevation of the shoulder. The greater tuberosity contacted the inferior or lateral surface of the acromion in most specimens with displacement greater than $1.0 \mathrm{~cm}$ posterior or superior. Acting as mechanical impedance to elevation of the shoulder, this may have contributed to the higher deltoid abduction forces which were recorded. Although more apparent with larger displacements, the influence of small amounts of superior translation $(0.5 \mathrm{~cm})$ is difficult to discern without measurements of subacromial pressure. Since visible contact was rarely observed with malunion of $0.5 \mathrm{~cm}$, decreased subacromial volumes with increased pressures may have contributed to increased abduction forces. Without such measurements, however, this relationship remains hypothetical and requires further investigation.

Although we used a previously validated model, we note the limitations of clinical correlation from a biomechanical investigation in vitro. The data show statistically significant increases in deltoid abduction forces which may not be clinically significant, since compensatory deltoid strengthening could possibly overcome the decrease in the abduc- tion moment arm of the rotator cuff. The clinical results of management are dependent on a number of variables in addition to displacement of the fracture. The effects of tears of the rotator cuff both pre-existing or simultaneously sustained, are not known since they may accelerate degeneration of the tendon complex and predispose to painful movement. Pain, by itself, after an injury, can substantially inhibit regaining movement.

In support of our data, we emphasise that the biomechanical model by design supplies a constant maximal force to the supraspinatus tendon. With this supraphysiological force, the peak deltoid forces observed are most likely to be underestimated. Furthermore, the fracture model simulates superior and posterior displacement only, while a large number of fractures in vivo also have considerable medial displacement. We believe that this would cause an additional mechanical disadvantage for the muscle, decreasing the available tendon excursion to aid abduction. Since the model does not simulate this loss of excursion, the increases in deltoid forces which are observed are, again, likely to be underestimations.

We wish to thank Dr S. von Hagen, $\mathrm{PhD}$, for his assistance in the statistical analysis.

No benefits in any form have been received or will be received from a commercial party related directly or indirectly to the subject of this article.

\section{References}

1. Neer C. Displaced proximal humeral fractures. J Bone Joint Surg [Am] 1979;53-A:1077-89.

2. Iannotti J, Sidor M. Malunions of the proximal humerus. In: Warner $\mathrm{J}$, Iannotti $\mathrm{J}$, Gerber $\mathrm{C}$, eds. Complex and revision problems in shoulder surgery. Philadelphia: Lippincott-Raven, 1997:245-64.

3. Neviaser J. Complicated fractures and dislocations about the shoulder joint. J Bone Joint Surg [Am] 1962;44-A:984-8.

4. Craig E. Open reduction and internal fixation of greater tuberosity fractures, malunions and nonunions. In: Craig E, ed. Master techniques in orthopaedic surgery: the shoulder. New York: Raven, Press, 1995:289-307.

5. Conner P, Flatow E. Complications of internal fixation of proximal humeral fractures. In: Springfield D, ed. Instructional Course Lectures. Rosemont: American Academy of Orthopaedic Surgeons, 1997:25-37.

6. Rasmussen S, Hvass I, Dalsgaard J, Christensen B, Holstad E. Displaced proximal humeral fractures: results of conservative treatment. Injury 1992;23:41-3.

7. DePalma A, Cautill R. Fractures of the upper end of the humerus. Clin Orthop 1961;20:73-93.

8. Stevens J. The action of the short rotator on the normal abduction of the arm, with a consideration of their action in some cases of subacromial bursitis and allied conditions. Am J Med Sci 1909; 138:870-84.

9. Karduna A, Williams GR, Williams JL, Iannotti JP. Kinematics of the glenohumeral joint: influences of muscle forces, ligamentous constraints, and articular geometry. J Orthop Res 1996;14:986-93.

10. Soslosky L, Flatow E, Bigliani L, Pawluk R, Ateshian G, Mow V. Quantitation of articular contact areas at the glenohumeral joint: a biomechanical study. J Orthop Res 1992;10:524-34.

11. Wuelker N, Wirth C, Plitz W, Roetman B. A dynamic shoulder model: reliability testing and muscle force study. J Biomechanics 1995;28:489-99.

12. Hughes R, An KN. Force analysis of rotator cuff muscles. Clin Orthop 1996;330:75-83.

13. Olivier H, Duparc J, Romain F. Fractures of the greater tuberosity of the humerus. Orthop Trans 1986;10:223. 
14. Young T, Wallace W. Conservative treatment of fractures and fracture-dislocation of the upper end of the humerus. J Bone Joint Surg [Br] 1985;67-B:373-7.

15. Flatow E, Cuomo F, Maday M, et al. Open reduction and internal fixation of two-part displaced fractures of the greater tuberosity of the proximal part of the humerus. J Bone Joint Surg [Am] 1991;73-A:1213-8.

16. Park T, Choi I, Kim Y, Park M, Shon J, Kim S. A new suggestion for the treatment of minimally displaced fractures of the greater tuberosity of the proximal humerus. Bull Hosp Jt Dis 1997;56:171-6.

17. Itoi E, Minagawa H, Sato T, Sato K, Tabata S. Isokinetic strength after tears of the supraspinatus tendon. J Bone Joint Surg [Br] 1997;79-B:77-82.
18. Kelly B, Kirkendall D, Levy A, Speer K. Current research on muscle activity about the shoulder. In: Springfield D. Instructional Course Lectures. Rosemont: American Academy of Orthopaedic Surgeons, 1997:53-66.

19. Wuelker N, Plitz W, Roetman B, Wirth C. Function of the supraspinatus muscle: abduction of the humerus studied in cadavers. Acta Orthop Scand 1994;65:442-6.

20. Thompson WO, Debski RE, Boardman ND III, et al. A biomechanical analysis of rotator cuff deficiency in a cadaveric model. Am J Sports Med 1996;24:286-92.

21. Minagawa H, Itoi E, Konno N, et al. Humeral attachment of the supraspinatus and infraspinatus tendons: an anatomic study. Arthroscopy $1998 ; 14: 302-6$. 